\title{
Esophageal Cancer in Golestan Province, Iran: A Review of Genetic Susceptibility and Environmental Risk Factors
}

\author{
Mahin Gholipour ${ }^{1}$, Farhad Islami ${ }^{2,3,4}$, Gholamreza Roshandel ${ }^{1}$, Masoud Khoshnia ${ }^{1}$, \\ Abbas Badakhshan ${ }^{5}$,Abdolvahab Moradi ${ }^{1 *}$, Reza Malekzadeh ${ }^{2}$
}

1. Golestan Research Center of Gastroenterology and Hepatology, Golestan University of Medical Sciences, Gorgan, Iran

2. Digestive Disease Research Center, Tehran University of Medical Sciences, Tehran, Iran

3. The Tisch Cancer Institute and Institute for Transitional Epidemiology, Icahn School of Medicine at Mount Sinai, New York, NY, USA

4. Surveillance and Health Services Research, American Cancer Society, Atlanta, GA, USA

5. Health Care Management Department, School of Public Health, Tehran University of Medical Sciences, Tehran, Iran

\footnotetext{
* Corresponding Author:

Abdolvahab Moradi, $\mathrm{PhD}$ Medical Faculty (FALSAFI), Golestan University of Medical Sciences, Hirkan BLV, Gorgan Tehran Road (kilometer 2), Gorgan-Iran Tel: + 981732421651 Fax: +981732440225 Email: Abmoradi@gmail.com
}

Received: 10 Jun. 2016 Accepted: 15 Oct. 2016

\section{ABSTRACT}

Esophageal squamous cell carcinoma (ESCC) is an aggressive tumor that is typically diagnosed only when the tumor has gained remarkable size, extended to peripheral tissues, and led to dysphagia. Five-year survival of advanced cancer is still very poor $(19 \%)$, even with improved surgical techniques and adjuvant chemoradiation therapy. Therefore, early detection and prevention are the most important strategies to reduce the burden of ESCC. Our review will focus on the studies conducted in Golestan province, an area with a high prevalence of ESCC in northern Iran. We review three aspects of the research literature on ESCC: epidemiological features, environmental factors (including substance abuse, environmental contaminants, dietary factors, and human papilloma virus $[\mathrm{HPV}]$ ), and molecular factors (including oncogenes, tumor suppressor genes, cell cycle regulatory proteins, and other relevant biomarkers). Epidemiological and experimental data suggest that some chemicals and lifestyle factors, including polycyclic aromatic hydrocarbons (PAHs), cigarette smoking, opium use, and hot tea drinking are associated with the development of ESCC in Golestan. HPV infects the esophageal epithelium, but so far, no firm evidence of its involvement in esophageal carcinogenesis has been provided. Some of these factors, notably hot tea drinking, may render the esophageal mucosa more susceptible to injury by other carcinogens. There are few studies at molecular level on ESCC in Golestan. Increasing awareness about the known risk factors of ESCC could potentially reduce the burden of ESCC in the region. Further studies on risk factors, identifying high risk populations, and early detection are needed.

\section{KEYWORDS:}

Genetically susceptibility; Environmental risk factors; Esophageal cancer; Golestan

\section{Please cite this paper as:}

Gholipour M, Islami F, Roshandel GR, Khoshnia M, Badakhshan A, Moradi A, Malekzadeh R. Esophageal Cancer in Golestan Province, Iran: A Review of Genetic Susceptibility and Environmental Risk Factors. Middle East J Dig Dis 2016:8:249-266. DOI :10.15171/ mejdd. 2016.34

\section{INTRODUCTION}

Esophageal cancer (EC) has two main histological subtypes, esophageal adenocarcinoma (EAC), and esophageal squamous cell carcinoma (ESCC). Although these subtypes originate from the same organ, their geographical distribution and etiology are different. ${ }^{1}$ The most common subtype of EC is ESCC, which predominantly is a disease of low- and middle-income regions such as central China and Golestan province in northeast Iran. ESCC in high-income countries are mainly related to tobacco smoking and much alcohol drinking, but in highincidence areas, some other factors are likely to be major risk factors of the cancer. EAC is related to overweight and gastroesophageal reflux 
disorder and is more common in high income communities ..$^{2,3}$

Despite more efficient surgical and chemical therapies, prognosis of EC is still poor (5-year survival $=19 \%){ }^{4}$ Many cases of EC are diagnosed at late stages, and currently no practical screening methods are available to identify early stage ECs at the population level. Therefore, identification of risk factors and preventive measures are the most important strategies to reduce the burden of cancer.

Golestan province in Iran has some of the highest reported incidence rates of ESCC in both men and women. For several reasons studies of ESCC in Golestan could be quite helpful in shedding light on the etiology of ESCC. In Golestan, the prevalence of smoking in men is moderate and alcohol drinking in both sexes and smoking among women are uncommon habits. Therefore, other risk factors of ESCC could be identified with little confounding effect from smoking and alcohol drinking. ${ }^{5} \mathrm{We}$ reviewed a number of epidemiological studies of ESCC in Golestan in an article published in $2009 .{ }^{6}$ As so, some other studies of ESCC in Golestan have been published since then, we aimed to update the previous summary. In addition, we will provide more detailed information about genetic factors and ESCC, because genome-wide association studies (GWAS) and other wide-ranging genetic studies in other populations have provided more insight on genetic factors in ESCC.

\section{Epidemiology}

ESCC is much more common in the so-called Asian EC belt, which starts from central and northern China and extends through central Asia and northern India to Golestan province. Central China and Golestan have the highest reported incidence rates of ESCC. ${ }^{7}$ Findings of some studies showed that the incidence rate of ESCC in Golestan province is 100 per 100000 (World Standard Population) age-adjusted men and women, which is considerable. ${ }^{8}$ Although a recent study has demonstrated some degrees of decline, the incidence rates of ESCC has remained high in both sexes. ${ }^{9}$

There are some other areas with relatively high incidence rates, including southeast Africa (e.g. some parts of Kenya and South Africa), parts of South America (e.g. some parts of Brazil and Uruguay), and Calvados in France. ${ }^{10}$ The lowest rates have been reported from high income countries in Europe and North America. ${ }^{11}$

The incidence rate of ESCC in Golestan is fairly higher in men than women (52\% in male patients) ${ }^{3}$, which is consistent with the pattern observed in Linxian (a high risk area in China) with a sex ratio of 1.5 , but absolutely contrary to the pattern of low incidence areas of Western countries (6.5 in France) where ESCC is much more common in men. ${ }^{12}$

Based on Golestan Population-based Cancer Registry between 2004 and 2008 the age-standardized incidence rates (ASRs) per 100,000 personyear for esophageal cancer were 24.3 in men and $19.1 \mathrm{in}$ women. The findings of a study in Gonbad and Kalaleh districts, located in the eastern area of the province, showed higher incidence rate of EC than other districts in both sexes. ${ }^{13}$

The risk of EC at age 75 years in the first-degree relatives of Turkmen patients and controls were $34 \%$ and $14 \%$, respectively $\left(\mathrm{HR}=2.3, \mathrm{P}=3 \times 10^{-8}\right)$. Also, $9.6 \%$ parents of the cases were related and $2.5 \%$ of the parents of the controls were related $(\mathrm{OR}=4.1, p=0.006) .{ }^{14} \mathrm{In}$ another case control study, Moradi and colleagues found that $21.6 \%$ of cases but no one in the control group had EC in their first degree relatives $(\mathrm{OR}=7.6, p=0.001) .{ }^{15}$ Since the role of family history have genetic and environmental elements in the pathogenesis of EC, more studies should be considered.

\section{Environmental Factors}

There are some reports that show factors including age, ethnicity, tobacco smoking, opium use, education, oral health, family history, and tea temperature were related to ESCC. Studying the nature and roles of these factors could be helpful in clinical practice and probably useful for identifying high risk individuals. ${ }^{16}$

\section{High-temperature foods and drinks}

High temperature foods and drinks can cause 
thermal damage to the esophagus. Such damage, if repeated, can predispose the users of high temperature food and drinks to EC. ${ }^{17}$ This association is consistent with the findings of other studies including what was conducted in the United Kingdom, South America, and Turkey. ${ }^{18}$

A study that was conducted in Golestan demonstrated a higher risk of $\mathrm{EC}$ due to drinking very hot tea $(\mathrm{OR}=8.16,95 \% \mathrm{CI}: 3.93-16.9)$ or hot tea $(\mathrm{OR}=2.07,95 \% \mathrm{CI}: 1.28$ - 3.35) compared with drinking warm or tepid tea. Regarding the tea drinking habits, almost all (98\%) Golestan cohort participants drank one liter of black tea per day. Some of them used to drink tea at temperature less than $60^{\circ} \mathrm{C}(39 \%)$ but, $38.9 \%$ drink tea at $60-64^{\circ} \mathrm{C}$, and others $(22 \%)$ at $65^{\circ} \mathrm{C}$ or higher.$^{19}$

\section{Tobacco, Alcohol, and Opium use}

Although above $90 \%$ of ESCCs in Western countries were associated with smoking and alcohol consumption ${ }^{20}$, the high risk areas of the central Asian EC belt, demonstrate less significant role in pathogenesis of ESCC. ${ }^{2}$ Some studies have shown the same relation in Golestan . ${ }^{3,18,21}$ Scant alcohol drinking in Golestan province indicates that it could not be a main cause of ESCC in this area, ${ }^{22}$ similar to what was seen in rural high risk areas of China.$^{23}$

In Golestan province, those who used tobacco $(\mathrm{OR}=1.70,95 \% \mathrm{CI}: 1.05-2.73)$, opium $(\mathrm{OR}=2.12$, 95\% CI: $1.21-3.74)$, or both tobacco and opium $(\mathrm{OR}=2.35,95 \% \mathrm{CI}: 1.50-3.67)$ were at a higher risk of ESCC compared with those who used neither tobacco nor opium.$^{24}$

In Golestan Cohort Study, 17\% of the participants reported ever opium use, with a mean duration of 12.7 years. Opium use was accompanied by increased risk of death from any digestive diseases (HR=1.55; $95 \%$ CI: 1.24-1.93), and long term opium use, was related to higher risk of death due to both malignant and non-malignant digestive diseases. ${ }^{25}$ In a study about sex-related opium consumption model, opium was used by men $(83 \%)$ much more than women $(13 \%))^{26}$ This huge difference is contrary to slight superiority of ESCC incidence in men compared with women, which was shown in another study.$^{13}$ Evaluating the exposure of women in this area to other risk factors could be useful to confirm this association.

\section{Low socioeconomic status}

A study aimed to find the relation between some socioeconomic status (SES) variables and risk of ESCC in Golestanian population based case control study. The strongest inverse association was found with education level. Compared with no education, primary education ( $\mathrm{AOR}=0.52$; $95 \% \mathrm{CI}: 0.27-0.98)$ and high school or beyond $(\mathrm{AOR}=0.20 ; 95 \% \mathrm{CI}$ : $0.06-0.65)$ were inversely associated with risk of ESCC. ${ }^{27}$ Consistent with the findings of Golestan, another study reported strong relation between SES and ESCC in Kashmir. ${ }^{28}$ In USA a study showed that the adjusted odds ratios for subjects with annual low incomes versus high incomes were 4.3 (95\% CI: $2.1-8.7)$ for white people and 8.0 (95\% CI: 4.3-15.0) for black people. This shows that low income in black people could lead to ESCC more than white people. ${ }^{29}$ SES plays its causation role in EC through some intermediate factors including behavior, lifestyle, environmental exposure, nutrition, and access to health care. ${ }^{30}$

\section{Polycyclic aromatic hydrocarbons}

There are many studies about the relationship between exposure to polycyclic aromatic hydrocarbons (PAHs) and ESCC. Indoor wood burning and road traffic are the major sources of PAHs. Both the WHO and the UK Expert Panel on Air Quality Standards (EPAQS) have considered benzo(a) pyrene $(\mathrm{BaP})$ as an indicative for the carcinogenic ability of the PAH mixture. ${ }^{31,32}$ The PAHs entering to the body through breathing, swallowing, and topical absorption, will cause metabolites that bind to cellular macromolecules. ${ }^{33}$ Cooking meat at high temperatures produces excessive amounts of PAHs and heterocyclic amines (HCAs). ${ }^{17}$ High temperature cooking and frying may be considered as causative factors of increased risk of ESCC in Golestan. $^{34}$

Two studies that were conducted in northeast Iran, showed some urinary levels of a PAH metabo- 
lite, which indicate exposure in more than $40 \%$ of the evaluated households, independent from other factors such as area of residence, smoking, sex, and nass or opium use. This was along with the pattern of SCC incidence. ${ }^{21,35}$ Although the amount of $\mathrm{BaP}$ in ordinary food and water of high risk areas (Golestan) is similar to other areas (south of Iran ), control participants from Golestan show more BaP intake than people living in low risk regions. Statistics show no association with BaP intake among the family members of patients' with ESCC, whereas living in low risk area was related to a significant decline in overall $\mathrm{BaP}$ consumption. In conclusion, $\mathrm{PAH}$ could be a factor for higher risk of ESCC in Golestan. ${ }^{36}$

Another study in this area showed that $41 \%$ of people had 1-hydroxypyrene glucuronide (1OHPG), a stable PAH metabolite that its levels more than $5 \mathrm{pmol} / \mathrm{mL}$, indicates very high exposure. Only $15 \%$ of the variance in $1-\mathrm{OHPG}$ was explained by age, sex, residential area, smoking, nass or opium use.$^{35} \mathrm{An}$ investigation about the pattern of non-smoking related exposure to PAHs has shown high exposure of PAHs in the general population and suggested that certain foods (red meat, processed meat), cooking methods (making bread at home), and genetic polymorphisms (GSTT1-02 and GSTM1-02) increased exposure to PAHs. ${ }^{37}$

\section{Fungus contamination of foods}

The toxin of fungus like fumonisin B1( FB1) is believed to have a positive correlation with EC. The geographic areas where FB1 exists in high concentrations have been associated with high rates of EC. ${ }^{38}$ FB1 has been classified by International Agency for Research on Cancer (IARC) as Group 2B carcinogen. ${ }^{39}$ In Golestan province $50 \%$ of corn and $40.9 \%$ of rice samples were contaminated by FB1. The proportion of FB1 contaminated rice samples was higher in high EC risk area than low risk area $(p=0.02) .{ }^{40}$ Researchers also found a positive relationship between aflatoxin level of wheat flour samples and the risk of EC in Golestan. ${ }^{41} \mathrm{Al}-$ though an earlier study did not suggest a major role for mycotoxins in EC.42 A pilot biomarker survey of women also revealed that fusarium mycotoxins exposure was normal compared to other areas of the world. ${ }^{43}$

\section{Silica}

In high incidence areas of ESCC, significant silica contamination of common food stuffs has been described, for example millet bran in northern China, wheat flour in Iran, and porridge made from 'Cape Chervil' in Transkei, South Africa. ${ }^{2}$ According to a recent study, the silica contamination of samples in Golestan was not more than the reference ranges. This change may be related to disposing of traditional milling methods or the fading of contaminating seeds in Golestan farms. ${ }^{2,6}$

\section{Vitamin deficiency}

Based on a survey using twelve 24-h dietary recalls administered monthly over a 13-month period, Islami and colleagues found severe inadequacy of vitamin intake in Golestan, particularly among women and rural dwellers. For example, the intake of vitamin $\mathrm{C}$ was below the recommended value in $41 \%$ of men and $64 \%$ of women in urban areas and $97 \%$ of men and $100 \%$ of women in rural areas. These deficiencies in nutrient intake may contribute to the higher risk of ESCC in Golestan, particularly in rural areas. Most of general population in Golestan province consumed protein more than the recommended values. ${ }^{44}$

\section{Poor oral health}

A study showed that increased risk of ESCC in Golestan (OR=2.37, 95\% CI: 1.42-3.97) was associated with poor oral hygiene and dental health. ${ }^{45}$ Also in another study in this area, researchers showed that coexistence of poor oral hygiene habit with gastric atrophy elevated the risk of ESCC eight times $(\mathrm{OR}=8.65,95 \%$ CI: $3.65-20.46){ }^{46}$

\section{Human papilloma virus (HPV)}

Among different types of human papilloma virus (HPV), serotype 16 has been suggested to have a role in the etiology of EC. Based on publication of IARC about HPV, this virus is detected more in 
patients with ESCC and there are many reviews about the association between HPV and ESCC, but these findings have been very inconsistent. This report concludes that part of this inconsistency could be explained by the absence of reliable tests. ${ }^{47} \mathrm{~A}$ study that was conducted in China concluded that findings did not support a major role for HPV16, HPV 18, and HPV73 in the etiology of EC..$^{48}$ Another study showed an important causal role for HPV particularly in high risk areas. HPV detection rates were $23 \%$ by using in situ hybridization and $15 \%$ by polymerase chain reaction in ESCC and oncogenic HPV types. ${ }^{49}$

There are some studies in Golestan, which evaluated the role of HPV in ESCC. The rates of HPV detection in ESCC specimens for men and women were $52.8 \%$ and $43.7 \%$, respectively, of which $54.7 \%$ were HPV-16. Results of this study support the possible role of HPV as an etiological agent in esophageal carcinogenesis. ${ }^{50}$ In another study at the same region, there was no significant difference in HPV infection between cancerous and non-cancerous tissue specimens of esophagus. ${ }^{51}$

Based on pooled analysis of six case-control studies from South Africa, Australia, Central and Eastern Europe, Brazil, Iran (Golestan), and China , limited serological evidence regarding the Associations between ESCC and HPV was found by researchers. They also were not able to exclude the role of some types of HPV in small subtypes of ESCC. ${ }^{52}$ According to aforementioned studies, the epidemiological evidence for the role of HPV in EC is unsatisfactory.

\section{Microbial factors}

Currently, the evidence that suggest the relation between microbes and EC is increasing. A study has revealed a significant association between the normal microbial flora of the upper gastrointestinal tract and esophageal squamous cell dysplasia as a precancerous lesion of esophagus. ${ }^{53}$ Periodontal disease microbiotome that is defined as collection of all members in a complex microbial community is full of gram negative bacteria. Porphyromonas gingivalis is the most important pathogen in mi- crobiotome, which has the ability to ruin epithelial cells and hinder immune reaction cell cycle mechanism. P. gingivalis was detected in $61 \%$ and $12 \%$ of cancerous and proximate tissues, respectively. ${ }^{54}$

A study that was conducted in China showed different amount of coordinates in ESCC compared with non-ESCC patients. This finding shows a relation between bacterial microbiota of saliva and risk of ESCC. ${ }^{55}$ Helicobacter pylori (H. pylori) is another gram negative bacteria that has commonly accused to have a precancerous role in gastroesophageal cancers. This bacterium that is specifically colonize the gastric epithelium, was regarded as the causative agent in infection-related cancers, which comprise $5.5 \%$ of the global cancer burden. ${ }^{56}$ A meta-analysis study about the relationship between H. pylori and EC, showed an opposite association between $H$. pylori and $\mathrm{EAC}(\mathrm{OR}=0.41$, 95\% CI: 0.28-0.62) and no association with ESCC $(\mathrm{OR}=1.08,95 \%$ CI: $0.76-1.53) .^{57}$

\section{Genetic susceptibility}

Studies have suggested the involvement of a large number of molecular events in the development and progression of ESCC, including genetic and epigenetic alterations in DNA repair genes, oncogenes, tumor suppressor genes, cell adhesion molecules, cell cycle regulatory genes, genetic instability, and telomerase activation. Nevertheless, the role of molecular mechanisms in the initiation, progression, and prognosis of ESCC are still poorly understood. ${ }^{58,59}$ The distinct risks that were shown in individuals exposed to the same known risk factors imply that genetic predisposition might play an important role in EC etiology. ${ }^{60}$

The pathological development of ESCC is a multi-step progressive process. The proliferation of esophageal epithelial cells is an early indicator of this process, which morphologically proceed to hyperplasia of basal cell, cell dysplasia, carcinoma in situ, and finally advanced EC. At the cellular level, the tumorogenesis process is related to abnormalities in the control of cell proliferation and differentiation and cell death (apoptosis). Most of cancerous cells contain genetic alterations, which indicate 
failure in the control process, including transcription factors and apoptosis related proteins. ${ }^{16,18}$ Two basic types of genetic damages are encountered frequently in cancerous cells: recessive (with targets known as tumor suppressor genes) and dominant (with targets known as oncogenes). ${ }^{61,62}$ Genetic factors related to ESCC are summarized as follows:

\section{Oncogenes}

Most normal cells will undergo a programmed form of rapid cell death (apoptosis) when their critical functions are altered. Oncogenes turn a healthy cell into a cancerous cell. Frequent mechanisms, activate these oncogenes, include point mutations, amplification, rearrangement and over-expression. ${ }^{63}$ Some of the oncogenes that are assessed in ESCC include:

\section{Epidermal growth factor receptor (EGFR)}

EGFR gene family translates proteins on cell membrane that act as receptors and has intracellular tyrosine kinase activity and extracellular binding domain. ${ }^{64}$ In a meta-analysis EGFR over-expression was positive in 722 of 1,150 patients (63\%) and was associated with higher depth of invasion and poor prognosis.65 Only the roles of two members of EGFR family (erbB-1 and erbB-2) have been investigated in ESCC. There is a tendency toward a worse prognosis in patients with erb-B-1 over-expression. ${ }^{10}$ Based on a study in central Asian high incidence areas, on 152 cases of ESCC from Iran (Tehran and Golestan province) and North India (Kashmir Valley), EGFR mutations appear to be a rare event. ${ }^{66}$

\section{Cyclin D1}

Cyclin D1 was shown to be associated with increased presence of lymph nodes metastases, distant metastases, high proliferative activity, high tumor grade, poor response to chemotherapy, and poor patients' survival. ${ }^{67}$ Because cyclin D1 has not been investigated in Golestan province, studying its expression could be informative and useful.

\section{Tumor suppressor genes}

Tumor suppressor genes are supportive genes.
Regularly, they control cell growth by monitoring cell division, repairing DNA mismatch, and controlling cell death. When a tumor suppressor gene is mutated, cells grow without control and may eventually form a tumor. Many tumor suppressor genes and the nuclear factors of the oncogenes control the expression of proteins that act as cell cycle regulators. The process can be inhibited by products of the proteins from the tumor suppressor genes such as p15, p16, p21, p27, p53 (indirectly through p21), and enhanced by c-myc protein. ${ }^{58}$ Some of tumor suppressor genes that have been studied in ESCC include:

\section{P53}

Over 100 ESCC mutations have been gathered in the IARC TP53 mutation database. The incidence of p53 mutation in ESCC is around 50\% and the frequency of mutations appears to be higher in high incidence areas. Accumulation of p53 in areas with esophagitis, suggested that the loss of suppressor function of p53 might be an early event in carcinogenesis of the esophagus. P53 is involved in multiple cellular pathways including transcriptional regulation, apoptosis, and cell cycle control. P53 single nucleotide polymorphisms(SNPs) reduce apoptosis and are associated with increased risk, earlier age of onset, chemotherapy resistance, and ECs relapse. In Japan, Kihara and colleagues found that the prognosis of patients with p53 mutated EC was significantly poorer (chemotherapy resistant) than patients whose tumors had no p53 mutations $(p=0.006)$. Although some results showed that patients with p53 mutations were likely to have a shorter survival but its relevance as a prognostic factor is still controversial.$^{10,58,62,68-71}$ In a recent study in Iran, no significant difference was found in the prevalence or pattern of p53 mutations between EC patients from northern Iran (Golestan) and Tehran, the capital of Iran, which is a low- to moderate-risk area for ESCC. ${ }^{72}$ But in a case control study in Golestan, it was shown that ESCC had the highest rate of TP53 mutations $(89.9 \%)$ ever reported in any cancer anywhere. These transversions include $40 \%$ at bases known as site of mutagenesis by PAHs. Mmutations showed different patterns according to tea consumption, but 
no variation in ethnicity, tobacco or opium use, alcoholic beverage consumption or urban versus rural residence. The heterogeneous mutation pattern is highly suggestive of a causative role for multiple environmental carcinogens, including PAHs. The temperature and composition of tea may also affect mutagenesis . ${ }^{73,74}$

\section{P21}

P21 protein is a cell cycle regulator that induces G1 arrest, leading to DNA repair or apoptosis. In response to DNA damage, wild type p53 assembles several downstream target genes including $\mathrm{p} 21$. The preliminary data suggested that $\mathrm{p} 21$ polymorphisms were not associated with development of ESCC in northeastern Iran, and gene-environment interaction analysis showed that cigarette smoking might have synergistic interactions with P21 C/A and p21 C/T genotype in ESCC carcinogenesis in this region. ${ }^{75}$

\section{P16INK4a}

Tumor suppressor genes, p16INK4a and p53, and the proto-oncogene, MDM2, are considered as essential G1 cell cycle regulatory genes whose loss of function is associated with ESCC carcinogenesis. Abnormal expression of $\mathrm{p} 16$ and p53, not MDM2, were significantly higher in the tumor tissue of ESCC patients in Golestan province. P16 gene silencing caused by hypermethylation of $\mathrm{CpG}$ islands may be a major mechanism in the ESCC development and is associated with overexpression of $\mathrm{p} 53$ protein. This is the first study demonstrating the relationship between p16 hypermethylation and overexpression of p53 protein.$^{76}$

\section{BRCA2}

BRCA2 is a nuclear protein with tumor suppressor activity through repairing DNA. A previous study from China suggested that BRCA2 might play a role in the etiology of ESCC. ${ }^{77}$ In Golestan six mutations that were screened in the coding region of BRCA2 gene in the germline DNA of Turkmen patients with ESCC, were judged to be pathogenic. In total, a suspicious deleterious BRCA2 variant was identified in $7.6 \%$ of patients with ESCC. ${ }^{78}$

\section{Single nucleotide polymorphisms (SNPs)}

Adding phase I SNPs and nucleotide excision repair (NER) capacity provided the best fit, and could explain $17 \%$ of the variation in adduct levels more than the environmental model of ESCC in Golestan cohort study. Female non-smokers in this population had PAH-related DNA adduct levels three to four times higher than smokers and occupationallyexposed groups in prior studies, with large inter-individual variation, which could best be explained by a combination of phase I genes and NER capacity.$^{79}$

\section{Genetic polymorphisms in enzymes}

Genetic polymorphisms may affect the activity of enzymes that metabolize carcinogens and make individuals more or less susceptible to the carcinogenic effects of the carcinogenic exposure. ${ }^{80}$ Cytochrome P450 (CYPs) is primarily responsible for the bioactivation of many low molecular weight carcinogens, including certain nitrosamines. Glutathione S-transferases (GSTs) are involved in detoxifying many other carcinogenic electrophiles including benzo(a)pyrene and other carcinogens in tobacco smoke, and alcohol dehydrogenases (ADHs)/aldehyde dehydrogenases (ALDs), which are alcohol-metabolizing enzymes. The data on genetic polymorphisms at the current status were still insufficient. ${ }^{10} \mathrm{ADH}$ oxidizes ethanol to acetaldehyde, which is itself oxidized to aldehyde by ALDH. Acetaldehyde has been demonstrated to be carcinogenic and therefore genetic variations resulting in functional differences in $\mathrm{ADH}$ and $\mathrm{ALDH}$ activity, which lead to increased levels of acetaldehyde in drinkers may be important. A number of ADH and ALDH families have been implicated in the pathogenesis of ESCC. ${ }^{2}$

An association was shown between inactive polymorphism of the GSTM1 gene and the presence of esophageal squamous dysplasia, in a PAHexposed population in China. Also, a significant higher expression of aryl hydrocarbon receptor (AhR) gene, which codes for the cell membrane receptor for PAHs, was reported in subjects from the same population who had a positive family history 
of upper gastrointestinal cancers. This indicates that these individuals might be more susceptible to PAH-related carcinogenesis. ${ }^{81}$

Among three Iranian ethnic groups, the frequencies of polymorphisms in ten genes that have been hypothesized to have a role in risk of EC were compared. Turkmens had higher frequency of four alleles that are speculated to favor carcinogenesis (CYP1A1 m1, CYP1A1 m2, CYP2A6*9, and $\mathrm{ADH} 2 * 1)$ compared with Zoroastrians. These results are consistent with an influence of these allele variants on the population risk of EC. However, none of these four alleles had a high enough prevalence in Turkmens to explain the high rates of EC in this ethnic group. Three of these four alleles (CYP1A1 m1,CYP1A1 m2, CYP2A6*9) were less frequent among Turkmens than in some Asian populations with lower risks of EC..$^{82}$ There are no case-control studies addressing the risk associated with these polymorphic genes and EC in Iranian patients, although a correlational study did not find a higher prevalence of susceptibility alleles of these genes among the high-risk Turkmens. ${ }^{83}$

22 functional variants (and 130 related tag SNPs) from 15 genes that have been associated previously with the risk of ESCC were evaluated in a case control study in Golestan province. The histidine allele at codon 48 of ADH1B gene was associated with a significantly decreased risk of ESCC in the joint data set under a recessive model $(\mathrm{OR}=0.41$, 95\% CI: $0.29-0.76, p=0.0004)$. The allele of the rs7087131 variant of MGMT (methyl guanine DNA methyltransferase) gene was associated with a decreased risk of ESCC under a dominant model ( $\mathrm{OR}=0.79,95 \%$ CI: $0.64-0.96, p=0.02)$. These results support the hypothesis that genetic predisposition plays a role in the high incidence of ESSC in Iran. ${ }^{84}$ Also in another study in Golestan, it was demonstrated that general population had high exposure to PAHs. The study suggested that certain foods (red meat intake, processed meat intake), cooking methods (making bread at home), and genetic polymorphisms (GSTT1-02, CYP1B1-07, GSTM1-02) increased exposure to PAHs. ${ }^{85}$

\section{NQO1(quinone oxidoreductase1)}

NQO1 is mainly a cytosolic enzyme, which catalyzes the reductive activation of quinoid chemotherapeutic agents and environmental carcinogens such as heterocyclic amines, nitrosamines, and condensates of the smoke like PAH. However, in the process of these metabolic reactions, some unstable PAH metabolites are highly reactive and may attack the DNA molecule, which results in the formation of PAH-DNA adducts.$^{86}$

In a meta-analysis it was shown that NQO1 C609T polymorphism increased the risk of ESCC $(\mathrm{OR}=2.03,95 \% \mathrm{CI}=1.29-3.19) .{ }^{87}$ In a study that was conducted in Golestan about the association between NQO1 and ESCC, predisposing role of NQO1 T allele for ESCC was not concluded. This study also revealed the role of PAHs as a risk factor of ESCC and the potential of PAH-DNA adducts for being a biomarker of risk for ESCC. ${ }^{88}$ Another study confirmed that the production of PAH-DNA adducts (DNA binding products), is a crucial step in PAH-initiated carcinogenesis. ${ }^{33}$ A study in Linxian showed PAH-DNA in esophageal biopsies and concluded that PAH-DNA adducts were a permanent indicator of PAH exposure. They recommended this indicator could be used in large studies looking for a relationship between PAH-DNA adduct and EC risk. ${ }^{89}$

\section{Fanconi anemia genes (FANC)}

Researchers sequenced the entire coding regions of 12 FANC in the germline DNA of Turkmen ESCC cases and identified three heterozygous insertion/deletion mutations. Both heterozygous and homozygous mutations in several FANC predisposing genes are associated with an increased risk of ESCC in Golestan province. ${ }^{90}$

\section{Matrix metalloproteinases 2(MMP-2)}

MMPs have a main role in cell life such as proliferation, migration, differentiation, angiogenesis, apoptosis. These enzymes have ability to destroy the proteins of extracellular matrix. Researcher induced inhibitory effects on the invasion and migration of the EC cell by suppressing MMP-2 expres- 
sion. ${ }^{91}$ Conversely, another study demonstrated that activating MMP-2 was associated with lymph node metastasis and lymphatic or vascular invasion. ${ }^{92}$

\section{Telomerase}

Repetitive telomere sequences at the ends of eukaryotic chromosomes protect the ends from damage and rearrangement. Progressive shortening of telomeric sequences is associated with cell division and DNA replication. Telomerase is a ribonucleoprotein reverse transcriptase that utilizes its own RNA template for the addition of telomeric sequences to chromosomal ends in order to maintain telomeric length. Li and colleagues showed that the positive rate of telomerase activity in ESCC cases was $83.3 \%$ and increased telomerase activity was associated with the progression of ESCC. Telomerase activity of ESCC cases in grade I (metaplasia), grade II (dysplasia), and grade III (high grade dysplasia) were $60 \%, 90 \%$, and $91 \%$, respectively. The poorer differentiation, and patients with lymphatic metastasis showed a higher telomerase activity than those without such findings..$^{93}$ There is not any study about this important aspect in Golestan as a high risk area.

\section{Proteins}

Keratins:

Keratins are intermediate filament forming cytoskeletal proteins with 30 indentified subtypes (CK 1-30). The diagnostic sensitivity of serum CK19 was correlated with tumor size, stages, and responsiveness to treatment and introduced CK19 as a potential useful prognostic marker for ESCC. ${ }^{94}$ Two representative tumor-associated proteins, HSP70 and HMGB1(especiallyHSP70), can induce autoantibody response in ESCC sera and have higher expression in ESCC tissues. ${ }^{95}$

\section{Hyaluronic acid and laminin}

They are non-collagenous components of the extracellular matrix, which are involved in several functions of cell, including proliferation, differentiation, migration, and cell adhesion. Several studies have reported increased serum levels of hyaluronic acid and laminin in various cancers and the correlation of the levels with poor prognosis. But, small data on the use of serum hyaluronic acid and laminin levels for early detection of EC are available .${ }^{96,97}$ In Golestan province, mean serum hyaluronic acid and laminin concentrations in incidental cancer cases were higher than in controls in crude analyses and substantial associations were indicated between hyaluronic acid levels and ESCC (beta coefficient $=0.332, p=0.05$ ) in multivariate models.$^{98}$

\section{Proteomics}

According to the first study on the proteomics of ESCC from Iran, Rastgar and co-workers showed that multiple proteins, which are generally affected in other digestive organs, are affected in ESCC, which may indicate a common molecular mechanism for digestive system tumor genesis and putative protein candidate biomarkers. Among the 14 differentially expressed proteins identified in this study, they observed loss of $\beta$-tropomyosin (TM $\beta$ ) in all tumor samples. Furthermore, this study additionally supports the involvement of TSs in the etiology of ESCC. ${ }^{99}$

\section{MicroRNAs (miRNA)}

Recently, a class of small non-coding RNAs, called miRNA, has been discovered, which can post transcriptionally silence protein expression. Some studies showed that different miRNAs play an important role in cell growth and carcinogenesis. ${ }^{100}$ Also miRNA acts in other biological and pathological processes including proliferation, differentiation, and apoptosis, and behaves as a biomarker for determining the types and sources of cance. ${ }^{101,102}$

There are few published data on miRNAs in ESCC. Some of miRNAs, which were associated with poor prognosis of ESCC are miR-103/107, miR-21, and MiR-27a. ${ }^{103-106}$ The detection of miRNAs will not only provide us with potential biomarkers for the early detection and prognostic assessment of human cancer but will also increase our understanding about their role in esophageal carcinogenesis. ${ }^{100}$ So the role of microRNAs in 
Table 1: Summary of evidence about the association between environmental factors and ESCC

\begin{tabular}{|c|c|c|c|c|}
\hline \multirow{2}{*}{$\begin{array}{l}\text { Risk factors } \\
\text { (RF) }\end{array}$} & \multicolumn{2}{|c|}{ Study Type (reference) } & \multicolumn{2}{|c|}{ Association and risk (reference) } \\
\hline & $\begin{array}{l}\text { Other } \\
\text { region }\end{array}$ & Golestan & Other regions & Golestan \\
\hline SES & $\begin{array}{l}\text {-Population based } \\
\text { case } \\
\text { control study }{ }^{29}\end{array}$ & $\begin{array}{l}\text { Population-based case } \\
\text { control study } 5,27,72\end{array}$ & $\begin{array}{l}\text {-Low annual incomes: } \\
A O R=4.3 \text { for white people } \\
A O R=8.0 \text { for black people } \\
\text {-Incidence rate }(\text { exposure to the } \\
\text { same RFs: black people }>\text { white } \\
\text { people } \\
\text {-Never married: } O R=3.9 \\
\text { - Low educational: } O R=3.1 \\
\text { - Low occupation: } O R=4.2 \\
\text {-Low socioeconomic: } O R=1.8^{29}\end{array}$ & $\begin{array}{l}\text {-Compared with no education: } \\
\text { primary education: } \mathrm{AOR}=0.52 \\
\text { >high school: } \mathrm{AOR}=0.20^{27} \\
\text {-Residence in urban areas: } \\
\text { HR: } 0.7 \\
\text { Non-Turkmen ethnic : HR }=0.76^{5} \\
\text {-No significant difference be- } \\
\text { tween Turkmen and non-Turkmen } \\
\text { ESCC cases in the prevalence of } \\
\text { exposure }\end{array}$ \\
\hline Smoking & $\begin{array}{l}\text {-population based } \\
\text { case control } \\
\text { study }{ }^{29}\end{array}$ & $\begin{array}{l}\text {-Cross sectional } \\
\text {-Case } \text { control }^{24}\end{array}$ & $\begin{array}{l}\text { Tobacco use in ESCC : } \\
\text { OR: } 3.1 \text { white males } \\
\text { OR: } 2.5 \text { black males }{ }^{29}\end{array}$ & $\begin{array}{l}\text {-Only } 27 \% \text { of ESCC patients had } \\
\text { ever smoked (similar to other } \\
\text { cancer and non-cancer groups) } \\
\text { - OR=1.70; } 95 \% \mathrm{CI}: 1.05-2.73^{24}\end{array}$ \\
\hline $\begin{array}{l}\text { Alcohol } \\
\text { consumption }\end{array}$ & $\begin{array}{l}\text {-Population based } \\
\text { case control } \\
\text { study }{ }^{29}\end{array}$ & $\begin{array}{l}\text { - Cross sectional } \\
\text { - Case control }^{24}\end{array}$ & $\begin{array}{l}\text { It is main RF: } \\
\text { OR: } 6.8 \text { white males } \\
\text { OR: } 8.3 \text { black males }{ }^{29}\end{array}$ & $\begin{array}{l}\text {-Only one of the } 144 \text { ESCC cases } \\
\text { had ever consumed alcohol, so } \\
\text { alcohol cannot be considered a } \\
\text { risk factor for ESCC }{ }^{3} \\
\text {-Alcohol consumption was seen } \\
\text { in only } 2 \% \text { of the cases and } 2 \% \text { of } \\
\text { the controls, and was not associ- } \\
\text { ated with ESCC risk }\end{array}$ \\
\hline $\begin{array}{l}\text { Opium } \\
\text { consumption }\end{array}$ & -------------- & $\begin{array}{l}\text {-Case control }{ }^{107,24} \\
\text { - Cohort }^{25}\end{array}$ & ------------------- & $\begin{array}{l}\text { - OR=2.12; 95\% CI:1.21-3.74 } \\
\text { - Opium use was associated with } \\
\text { a significantly increased } \\
\text { risk of ESCC: AOR } 1.77,95 \% \mathrm{CI} \\
1.17-2.68{ }^{107} \\
\text { - AHR for all mortality causes } \\
\text { associated with use of opium was } \\
1.86(95 \% \mathrm{CI}, 1.68-2.06)^{25}\end{array}$ \\
\hline $\begin{array}{c}\text { PAH } \\
\text { exposure }\end{array}$ & - Review $^{17}$ & $\begin{array}{l}\text {-Case control }{ }^{36} \\
\text {-Cross sectiona }^{135}\end{array}$ & $\begin{array}{l}\text { - Intakes are thought to be } \\
\text { relatively high in Europe, although } \\
\text { measures are only available from } \\
\text { a few, generally high-income } \\
\text { countries. }{ }^{17}\end{array}$ & $\begin{array}{l}\text { - BaP daily intake in controls: } \\
\text { high-risk area (Golestan) }>\text { low- } \\
\text { risk area ( } 91.4 \text { vs. } 70.6 \mathrm{ng} / \text { day, } \\
\mathrm{p}<0.01)^{36} \\
-41 \% \text { of people in Golestan ( } 1 \text { - } \\
\text { OHPG) }>5 \mathrm{pmol} / \mathrm{mL} \text { (very high } \\
\text { exposure) }\end{array}$ \\
\hline $\begin{array}{l}\text { Fungus } \\
\text { contamination } \\
\text { of foods }\end{array}$ & $\begin{array}{l}\text {-Cross sectional } \\
\text { (ecological } \\
\text { study) })^{38}\end{array}$ & $\begin{array}{l}\text {-Cross sectional } \\
\text { (ecologic study) } \\
\text {-Cross sectional } \\
\text { (ecologic study })^{41}\end{array}$ & $\begin{array}{l}\text { FB1 and FB2 levels were sig- } \\
\text { nificantly higher in high risk area } \\
(\mathrm{p}=0.01)^{38}\end{array}$ & $\begin{array}{l}\text {-FB1-contaminated rice: } \\
\text { High-risk area }(75 \%)>\text { low risk } \\
(21.4 \%)(\mathrm{p}=0.02) 40 \\
\text {-AF level of wheat flour: } \\
\text { Total AF and AFB1 were } \\
\text { significantly higher in samples } \\
\text { obtained from high risk area }{ }^{41}\end{array}$ \\
\hline
\end{tabular}




\begin{tabular}{|c|c|c|c|c|}
\hline \multirow{2}{*}{$\begin{array}{l}\text { Risk factors } \\
\text { (RF) }\end{array}$} & \multicolumn{2}{|c|}{ Study Type (reference) } & \multicolumn{2}{|c|}{ Association and risk (reference) } \\
\hline & $\begin{array}{l}\text { Other } \\
\text { region }\end{array}$ & Golestan & Other regions & Golestan \\
\hline $\begin{array}{l}\text { Oral and den- } \\
\text { tal hygiene }\end{array}$ & $\begin{array}{l}\text { Population based Case } \\
\text { control study }{ }^{29}\end{array}$ & $\begin{array}{l}\text { Population-based } \\
\text { Case control } \\
\text { study }^{45,46}\end{array}$ & $\begin{array}{l}\text {-Rarely visited a dentist in ESCC } \\
\text { cases: } \\
\mathrm{OR}=1.8 \text { for white people } \\
\mathrm{OR}=1.7 \text { for black people } \\
\text {-Rarely visited a dentist at or below } \\
\text { the poverty level: } \\
\mathrm{OR}=2.6 \text { for white people } \\
\mathrm{OR}=4.2 \text { for black people }\end{array}$ & $\begin{array}{l}\text { - Poor oral hygiene in ESCC: } \\
\qquad \mathrm{OR}=2.37^{45} \\
\text {-Poor oral hygiene with gastric } \\
\text { atrophy elevated ESCC risk: } \\
\qquad \mathrm{OR}=8.65^{46}\end{array}$ \\
\hline $\mathrm{HPV}$ & $\begin{array}{c}\text { - Review }{ }^{10} \\
\text { - Pooled from six case } \\
\text { control studies }{ }^{52}\end{array}$ & $\begin{array}{l}\text {-Cross sectional } \\
- \text { Case }^{50} \text { control }^{51}\end{array}$ & $\begin{array}{l}\text { HPV in ESCC: } \\
\text { 1- United States: } 3 \% \text {, } \\
\text { - High risk areas in Asia (Japan, } \\
\text { China, Hong Kong, India, Pakistan, } \\
\text { and Korea), South Africa, Alaska, } \\
\text { and Australia: } 13 \text { - } 63 \% \text { ( overall } \\
22 \% .)^{10} \\
\text { 2- South Africa, Australia, Central } \\
\text { and Eastern Europe, Brazil, Iran, } \\
\text { and China: } \\
\text {-E6 antibody: } \\
\text { HPV16: OR=1.89 } \\
\text { HPV6: OR }=2.53\end{array}$ & $\begin{array}{c}\text { 1- HPV in ESCC: } \\
\text { - men: } 52.8 \% \\
\text {-women : } 43.7 \% \\
\text { positive cases HPV-16: } 54.7 \% 0^{50} \\
\text { 2- No significant difference } \\
\text { between cancerous and non- } \\
\text { cancerous }^{51}\end{array}$ \\
\hline
\end{tabular}

\begin{tabular}{|c|c|c|}
\hline $\begin{array}{l}\text { Low level of } \\
\text { vitamin A\&C } \\
\text { intake }\end{array}$ & -Systematic review ${ }^{59}$ & $\begin{array}{l}\text {-Cross sectional in } \\
\text { healthy participants } \\
\text { in Golestan }{ }^{44}\end{array}$ \\
\hline
\end{tabular}

Low level of intake in Golestan ${ }^{44}$
- A decreased risk associated with high retinol and $\beta$-carotene intake (combined OR $=0.66,95 \%$ CI:0.54$0.81)^{59}$
-Severe deficiency in vitamin intake among women and rural dwellers in Golestan: Daily intake (rural women) < LTI (lowest threshold intakes): vitamin A: 67\% $(\mathrm{p}<0.01)$ vitamin $\mathrm{C}: 73 \%{ }^{44}$

\begin{tabular}{|c|c|c|c|c|}
\hline $\begin{array}{l}\text { High tempera- } \\
\text { ture cooking } \\
\text { and frying (di- } \\
\text { etary intake of } \\
\text { heterocyclic } \\
\text { amines) }\end{array}$ & $\begin{array}{l}\text { Population-based } \\
\text { Case control study }\end{array}$ & Case control & $\begin{array}{l}\text { Heterocyclic amine intake might be } \\
\text { associated with an increase in risk } \\
\text { of ESCC ( } 50-70 \% \text { increased risk) }\end{array}$ & $\begin{array}{c}\text {-Frying index: } \mathrm{p}<0.01 \\
\text { ESCC cases: } 18.2: 1 \\
\text { High risk controls: } 12.8: 1 \\
\text { Low risk controls: } 2.6: 1 \\
\text {-Cooking oil reuse: } \mathrm{p}<0.05 \\
\text { ESCC cases: } 37.5 \% \\
\text { High risk controls: } 25 \% \\
\text { Low risk controls: } 7.5 \%\end{array}$ \\
\hline $\begin{array}{l}\text { Hot beverage } \\
\text { consumption }\end{array}$ & --------------- & Case control & ---------------- & $\begin{array}{c}\text { Risk compared to warm : } \\
\text {-hot black tea (OR: } 2.07) \\
\text {-very hot black tea (OR:8.16) }\end{array}$ \\
\hline
\end{tabular}

SES: socioeconomic status, AOR: adjusted odds ratio, OR: odds ratio, ESCC: Esophageal squamous cell carcinoma, AHR: djusted Hazard Ratio, PAH: polycyclic aromatic hydrocarbons, BaP: benzo(a)pyrene, FB1 and FB2: fumonisin B1\& B2, P: P.value, HPV: Human papilloma virus, CI: confidence interval

ESCC, from providing non-aggressive biomarkers to their potential role in producing modern therapeutic measures make them attractive to researchers.

\section{CONCLUSION}

EC is still one of the most lethal diseases despite the improved approaches for diagnosis, prevention, and treatment. EC pose a considerable medical and public health challenge in many parts of the world.
The development of EC is a multifactorial process associated with a variety of risk factors. The high incidence of EC in certain parts of the world indicates a role for environmental as well as habitual factors in addition to genetics. Therefore, greater effort is desired to comprehensively understand the molecular biology of esophageal carcinogenesis especially in high risk regions like Caspian littoral.

The insight into cancer biology could be trans- 
Table 2: Summary of evidence about the association between genetic factors and ESCC

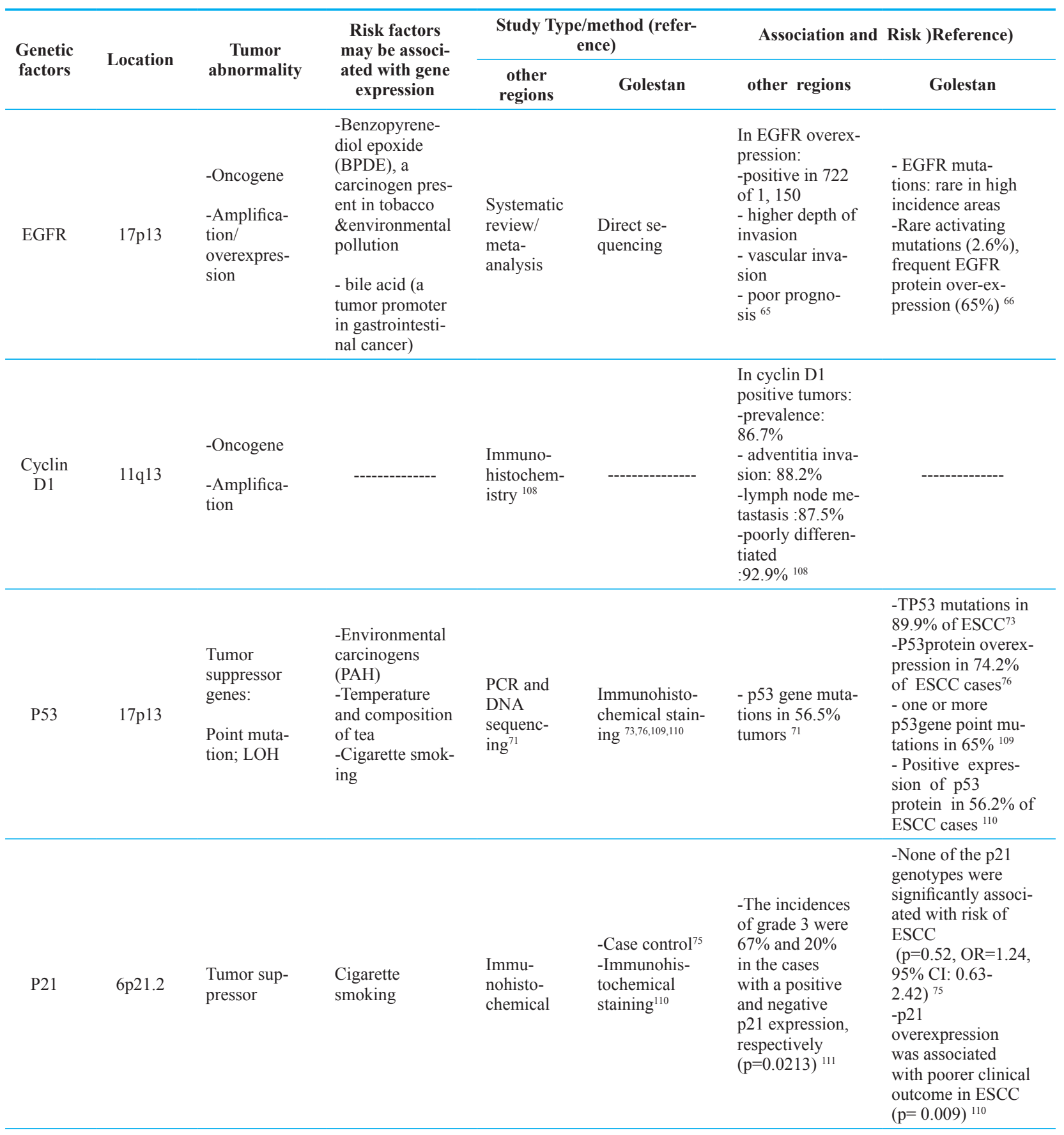

lated into practical approaches for the diagnosis, treatment, and prevention of EC. Low socioeconomic status, certain nutritional deficiencies, cigarette smoking, nass chewing, opium use, hot tea consumption, and poor oral hygiene are the en- vironmental risk factors that are associated with ESCC risk in Golestan province. Other suggested risk factors are exposure to PAHs, nitrosamines, silica fibers, and infectious agents. HPV infects the esophageal epithelium, but so far, no firm evidence 


\begin{tabular}{|c|c|c|c|c|c|c|c|}
\hline \multirow{2}{*}{$\begin{array}{l}\text { Genetic } \\
\text { factors }\end{array}$} & \multirow{2}{*}{ Location } & \multirow{2}{*}{$\begin{array}{c}\text { Tumor } \\
\text { abnormality }\end{array}$} & \multirow{2}{*}{$\begin{array}{l}\text { Risk factors } \\
\text { may be associ- } \\
\text { ated with gene } \\
\text { expression }\end{array}$} & \multicolumn{2}{|c|}{$\begin{array}{c}\text { Study Type/method (refer- } \\
\text { ence) }\end{array}$} & \multicolumn{2}{|c|}{ Association and Risk )Reference) } \\
\hline & & & & $\begin{array}{l}\text { other } \\
\text { regions }\end{array}$ & Golestan & other regions & Golestan \\
\hline p16 & $9 \mathrm{p} 22$ & $\begin{array}{l}\text { Tumor sup- } \\
\text { pressor: } \\
\text { homozy- } \\
\text { gous loss, } \\
\text { promoter } \\
\text { methylation }\end{array}$ & $\begin{array}{l}\text { Roasting meat } \\
\text { intake }\end{array}$ & $\begin{array}{l}\text {-Immu- } \\
\text { nohisto- } \\
\text { chemical } \\
\text { staining }{ }^{112} \\
\\
\text {-case con- } \\
\text { trol }^{113}\end{array}$ & $\begin{array}{l}\text { Immunohis- } \\
\text { tochemical } \\
\text { staining }{ }^{76}\end{array}$ & $\begin{array}{l}\text {-The expression of } \\
\text { p16INK4a was } 88 \% \\
\text { in ESCC cases }{ }^{112} \\
\text {-Daily roasting } \\
\text { meat intake was } \\
\text { related to the risk } \\
\text { of ESCC ( }<0.01 \text { ) } \\
\text { and the mean CpG } \\
\text { methylation rates } \\
\text { of p16 promoter } \\
(p<0.01) .{ }^{113}\end{array}$ & $\begin{array}{l}\text { - p16INK4a } \\
\text { gene aberrant } \\
\text { methylation in } \\
62 \% \text { of esopha- } \\
\text { geal tumor } \\
\text { samples }^{76}\end{array}$ \\
\hline NQO1 & $16 \mathrm{q} 22$ & $\begin{array}{l}\text { Enzymes } \\
\text { involved in } \\
\text { metabolism } \\
\text { of carcino- } \\
\text { gens }\end{array}$ & $\begin{array}{l}\text { Environmental } \\
\text { carcinogens: } \\
\text { heterocy- } \\
\text { clic amines, } \\
\text { nitrosamines } \\
\text { and cigarette } \\
\text { smoking }\end{array}$ & $\begin{array}{l}\text { Systematic } \\
\text { review/ } \\
\text { meta-anal- } \\
\text { ysis }{ }^{87}\end{array}$ & $\begin{array}{l}\text { Case control } \\
\text { study }\end{array}$ & $\begin{array}{l}\text {-NQO1 C609T } \\
\text { polymorphism } \\
\text { increases the risk of } \\
\text { ESCC }(\mathrm{OR}=2.03,95 \% \\
\mathrm{CI}=1.29-3.19) \text { in a } \\
\text { meta-analysis }\end{array}$ & $\begin{array}{l}\text { NQO1gene } \\
\text { expression was } \\
\text { high in normal } \\
\text { esophageal tis- } \\
\text { sues }{ }^{88}\end{array}$ \\
\hline
\end{tabular}

Location: gene's "address" on a chromosome. EGFR: Epidermal growth factor receptor, NQO1: quinone oxidoreductase1

of its involvement in esophageal carcinogenesis has been provided. Most of these factors render the esophageal mucosa more susceptible to injury by carcinogens. The effect of environmental factors is not independent of cancer genes.

Overall, molecular research on ESCC focuses on the factors related to pathogenesis and prognosis. These include topics like etiopathogenesis (cancer susceptibility genes), keratins expression, tumor related genes (oncogenes, tumor suppressor genes, genes involved in metastasis, and apoptosis genes), proliferation-related factors (nuclear proteins), and factors related to metastases (cell adhesion molecules and enzymes related to degradation of extracellular matrix).

As tables 1 and 2 show, we summarized evidence, which were found in Golestan province and compared them with other evidence, which were found in other similar regions in the world. We have a lot of evidence about environmental factors but there are a few studies in molecular level in Golestan. So there is an obvious need for further studies not only for screening ESCC in curable phase but also for developing the treatment. Future molecular epide- miological studies would be helpful in identifying high risk populations, early screening and diagnosis, and guiding individual clinical treatment of EC.

\section{CONFLICT OF INTEREST:}

The authors declare no conflict of interest related to this work.

\section{REFERENCES}

1. Lao-Sirieix P, Caldas C, Fitzgerald RC. Genetic predisposition to gastro-oesophageal cancer. Curr Opin Genet Dev 2010;20:210-7. doi: 10.1016/j.gde.2010.03.002

2. Melhado RE, Alderson D, Tucker O. The changing face of esophageal cancer. Cancers 2010;2:1379-404. doi: $10.3390 /$ cancers 2031379

3. Islami F, Kamangar F, Aghcheli K, Fahimi S, Semnani S, Taghavi N, et al. Epidemiologic features of upper gastrointestinal tract cancers in Northeastern Iran. Br J Cancer 2004;90:1402-6. doi: 10.1038/sj.bjc.6601737

4. Jemal A, Siegel R, Xu J, Ward E. Cancer statistics, 2010. CA Cancer J Clin 2010;60:277-300. doi: 10.3322/ caac. 20073

5. Aghcheli K, Marjani HA, Nasrollahzadeh D, Islami F, Shakeri R, Sotoudeh M, et al. Prognostic factors for esophageal squamous cell carcinoma--a population-based study in Golestan Province, Iran, a high incidence area. PloS One 2011;6:e22152. doi: 10.1371/journal.pone.0022152

6. Islami F, Kamangar F, Nasrollahzadeh D, Moller H, Bof- 
fetta P, Malekzadeh R. Oesophageal cancer in Golestan Province, a high-incidence area in northern Iran - a review. Eur J Cancer 2009;45:3156-65. doi: 10.1016/j. ejca.2009.09.018

7. Blot WJ MJ, Fraumeni JF. Esophageal Cancer. In: Schottenfeld D FJ, eds, editor. Cancer Epidemiology and Prevention. Oxford:Oxford University Press 2006. p. 697706.

8. Mahboubi E, Kmet J, Cook P, Day N, Ghadirian P, Salmasizadeh S. Oesophageal cancer studies in the Caspian Littoral of Iran: the Caspian cancer registry. Br J Cancer 1973;28:197. doi: 10.1002/ijc.2910350505

9. Semnani S, Sadjadi A, Fahimi S, Nouraie M, Naeimi M, Kabir J, et al. Declining incidence of esophageal cancer in the Turkmen Plain, eastern part of the Caspian Littoral of Iran: A retrospective cancer surveillance. Cancer Detect Prev 2006;30:14-9. doi: 10.1016/j.cdp.2005.11.002

10. Lam AK. Molecular biology of esophageal squamous cell carcinoma. Crit Rev Oncol Hematol 2000;33:71-90. doi: 10.1016/S1040-8428(99)00054-2

11. Jemal A, Center MM, DeSantis C, Ward EM. Global patterns of cancer incidence and mortality rates and trends. Cancer Epidemiol Biomarkers Prev 2010;19:1893-907 doi: 10.1158/1055-9965.EPI-10-0437

12. Schottenfeld D. Cancer epidemiology and prevention: Oxford University Press; 2006. doi: 10.1093/acprof:o so/9780195149616.001.0001

13. Roshandel G, Sadjadi A, Aarabi M, Keshtkar A, Sedaghat SM, Nouraie SM, et al. Cancer incidence in Golestan Province: report of an ongoing population-based cancer registry in Iran between 2004 and 2008. Arch Iran Med 2012;15:196-200. doi: 012154/AIM.004

14. Akbari MR, Malekzadeh R, Nasrollahzadeh D, Amanian $\mathrm{D}$, Sun P, Islami F, et al. Familial risks of esophageal cancer among the Turkmen population of the Caspian littoral of Iran. Int J Cancer 2006;119:1047-51. doi:10.1002/ ijc. 21906

15. Moradi A KK, Qujeq D, Ghaemi EO, Marjani A, Ghourchaei A. Risk factors associated with esophageal cancer in north of Iran. Saudi Med J 2007;28:1141-3. doi: 10.17795/jjcdc-33229

16. Etemadi A, Abnet CC, Golozar A, Malekzadeh R, Dawsey SM. Modeling the Risk of Esophageal Squamous Cell Carcinoma and Squamous Dysplasia in a High Risk Area in Iran. Arch Iran Med 2012;15:18-21. doi: 012151/ AIM.007.

17. Marmot M, Atinmo T, Byers T, Chen J, Hirohata T, Jackson A, et al. Food, nutrition, physical activity, and the prevention of cancer: a global perspective. 2007.

18. Pourshams A, Saadatian-Elahi M, Nouraie M, Malekshah AF, Rakhshani N, Salahi R, et al. Golestan cohort study of oesophageal cancer: feasibility and first results. $\mathrm{Br} J$ Cancer 2005;92:176-81. doi: 10.1038/sj.bjc.6602249

19. Islami F, Pourshams A, Nasrollahzadeh D, Kamangar F, Fahimi S, Shakeri R, et al. Tea drinking habits and oe- sophageal cancer in a high risk area in northern Iran: population based case-control study. BMJ 2009;338:b929. doi: 10.1136/bmj.b929

20. Zhang HZ, Jin GF, Shen HB. Epidemiologic differences in esophageal cancer between Asian and Western populations. Chin J Cancer 2012;31:281-6. doi: 10.5732/ cjc.011.10390.

21. Pourshams A, Khademi H, Malekshah AF, Islami F, Nouraei M, Sadjadi AR, et al. Cohort Profile: The Golestan Cohort Study--a prospective study of oesophageal cancer in northern Iran. Int $J$ Epidemiol 2010;39:52-9. doi: 10.1093/ije/dyp161.

22. Kamangar F, Malekzadeh R, Dawsey SM, Saidi F. Esophageal cancer in Northeastern Iran: a review. Arch Iran Med 2007;10:70-82 . doi:07101/AIM.0016

23. Tran GD, Sun XD, Abnet CC, Fan JH, Dawsey SM, Dong ZW, et al. Prospective study of risk factors for esophageal and gastric cancers in the Linxian general population trial cohort in China. Int J Cancer 2005;113:456-63. doi: 10.1002/ijc. 20616

24. Nasrollahzadeh D, Kamangar F, Aghcheli K, Sotoudeh M, Islami F, Abnet CC, et al. Opium, tobacco, and alcohol use in relation to oesophageal squamous cell carcinoma in a high-risk area of Iran. BrJ Cancer 2008;98:1857-63. doi: 10.1038/sj.bjc.6604369.

25. Khademi H, Malekzadeh R, Pourshams A, Jafari E, Salahi $\mathrm{R}$, Semnani S, et al. Opium use and mortality in Golestan Cohort Study: prospective cohort study of 50,000 adults in Iran. BMJ 2012;344:e2502. doi: 10.1136/bmj.e2502

26. Keshtkar A, Majdzadeh R, Nedjat S, Gholipour M, Badakhshan A, Qorbani M, et al. Characteristics of High-Risk Sexual Behaviors for Human Immunodeficiency Virus Infection Among Iranian Drug Abusers. $J$ Addict Med 2012;6:153-8. doi: 10.1097/ADM.0b013e31823f5fa7.

27. Islami F, Kamangar F, Nasrollahzadeh D, Aghcheli K, Sotoudeh M, Abedi-Ardekani B, et al. Socio-economic status and oesophageal cancer: results from a populationbased case-control study in a high-risk area. Int $J$ Epidemiol 2009;38:978-88. doi: 10.1093/ije/dyp195.

28. Dar NA, Shah IA, Bhat GA, Makhdoomi MA, Iqbal B, Rafiq R, et al. Socioeconomic status and esophageal squamous cell carcinoma risk in Kashmir, India. Cancer Sci 2013;104:1231-6. doi: 10.1111/cas.12210

29. Brown LM, Hoover R, Silverman D, Baris D, Hayes R, Swanson GM, et al. Excess incidence of squamous cell esophageal cancer among US Black men: role of social class and other risk factors. Am J Epidemiol 2001;153:11422. doi: $10.1093 /$ aje/153.2.114

30. Shavers VL. Measurement of socioeconomic status in health disparities research. J Natl Med Assoc 2007;99:1013-23.

31. Delgado-Saborit JM, Stark C, Harrison RM. Carcinogenic potential, levels and sources of polycyclic aromatic hydrocarbon mixtures in indoor and outdoor environments and their implications for air quality standards. Environ 
Int. 2011;37:383-92. doi: 10.1016/j.envint.2010.10.011

32. Poirier MC. Chemical-induced DNA damage and human cancer risk. Nat Rev Cancer 2004;4:630-7. doi :10.1038/ $\operatorname{nrc} 1410$

33. Pratt MM, John K, MacLean AB, Afework S, Phillips DH, Poirier MC. Polycyclic aromatic hydrocarbon (PAH) exposure and DNA adduct semi-quantitation in archived human tissues. Int J Environ Res Public Health 2011;8:2675-91. doi: 10.3390/ijerph8072675

34. Hakami R EA, Kamangar F, Pourshams A, Mohtadinia J, Firoozi MS, Birkett N, Boffetta P, Dawsey SM, Malekzadeh R. Cooking methods and esophageal squamous cell carcinoma in high-risk areas of Iran. Nutr Cancer 2014;66:500-5. doi: 10.1080/01635581.2013.779384

35. Kamangar F, Strickland PT, Pourshams A, Malekzadeh R, Boffetta P, Roth MJ, et al. High exposure to polycyclic aromatic hydrocarbons may contribute to high risk of esophageal cancer in northeastern Iran. Anticancer Res 2005;25:425-8.

36. Hakami R, Mohtadinia J, Etemadi A, Kamangar F, Nemati M, Pourshams A, et al. Dietary intake of benzo(a)pyrene and risk of esophageal cancer in north of Iran. Nutr Cancer 2008;60:216-21. doi: 10.1080/01635580701684831

37. Islami F, Boffetta P, Van Schooten FJ, Strickland P, Phillips DH, Pourshams A, et al. Exposure to polycyclic aromatic hydrocarbons among never smokers in Golestan Province, Iran, an area of high incidence of esophageal cancer-a cross-sectional study with repeated measurement of urinary 1-OHPG in two seasons. Front Oncol 2012;2. doi: 10.3389/fonc.2012.00014

38. Rheeder JP SE, Marasas WFO. Fusarium moniliforme and fumonisins in corn in relation to human oesophageal cancer in Transkei. Phytopathology 1992;82:353-7. doi: 10.1094/Phyto-82-353

39. IARC. IARC Monographs on the evaluation ofcarcinogenic risks t o humans. Lyon,France International Agency for Research on Cancer (IARC), 2002.

40. Alizadeh A. Roudbarmohammadi S. Fumonisin B1 Contamination of Cereals and Risk of Esophageal Cancer in a High Risk Area in Northeastern Iran. Asian Pac J Cancer Prev 2012;13:2625-8.

41. Ghasemi-Kebria F, Joshaghani H, Taheri NS, Semnani S, Aarabi M, Salamat F, et al. Aflatoxin contamination of wheat flour and the risk of esophageal cancer in a high risk area in Iran. Cancer Epidemiol 2013;37:290-3. doi: 10.1016/j.canep.2013.01.010

42. Lacey J. The microbiology of cereal grains from areas of Iran with a high incidence of oesophageal cancer. $J$ Stored Prod Res1988;24:39-50.

43. Turner P, Gong Y, Pourshams A, Jafari E, Routledge M, Malekzadeh R, et al. A pilot survey for Fusarium mycotoxin biomarkers in women from Golestan, Northern Iran. World Myco J 2012;5:195-9.

44. Islami F, Malekshah AF, Kimiagar M, Pourshams A, Wakefield J, Goglani G, et al. Patterns of food and nu- trient consumption in northern Iran, a high-risk area for esophageal cancer. Nutr Cancer 2009;61:475-83. doi: $10.1080 / 01635580902803735$

45. Abnet CC, Kamangar F, Islami F, Nasrollahzadeh D, Brennan P, Aghcheli K, et al. Tooth loss and lack of regular oral hygiene are associated with higher risk of esophageal squamous cell carcinoma. Cancer Epidemiol Biomarkers Prev 2008;17:3062-8. doi: 10.1158/1055-9965. EPI-08-0558

46. Nasrollahzadeh D, Malekzadeh R, Aghcheli K, Sotoudeh $\mathrm{M}$, Merat S, Islami F, et al. Gastric atrophy and oesophageal squamous cell carcinoma: possible interaction with dental health and oral hygiene habit. $\mathrm{Br} J$ Cancer 2012;107:888-94. doi: 10.1038/bjc.2012.332

47. Bouvard V, Baan R, Straif K, Grosse Y, Secretan B, Ghissassi FE, et al. A review of human carcinogens-Part B: biological agents. Lancet Oncol 2009;10:321-2. doi: 10.1016/S1470-2045(09)70096-8

48. Kamangar F, Qiao YL, Schiller JT, Dawsey SM, Fears $\mathrm{T}$, Sun XD, et al. Human papillomavirus serology and the risk of esophageal and gastric cancers: Results from a cohort in a high-risk region in China. Inter $J$ Cancer 2006;119:579-84. doi:10.1002/ijc.21871

49. Syrjänen K. HPV infections and oesophageal cancer. $J$ Clin Pathol 2002;55:721-8. doi:10.1136/jcp.55.10.721

50. Moradi A, Villiers E, Mokhtari-Azad T, Mahmoudi M, Hazrati B, Ghaemi EE, et al. Detection of human papillomavirus DNA by PCR in esophageal squamous cell carcinoma from Turkmen Sahra, north-east of Iran. Iran Biomed J 2002;6:19-23.

51. Moradi A, Mokhtari-Azad T. Detection of HPV in cancerous and non-cancerous esophageal tissues from TurkmenSahra, Iran. Int J Cancer Res 2006;2:113-8. doi: 10.3923/ ijcr.2006.113.118

52. Sitas F, Egger S, Urban MI, Taylor PR, Abnet CC, Boffetta $\mathrm{P}$, et al. InterSCOPE study: Associations between esophageal squamous cell carcinoma and human papillomavirus serological markers. J Nat Cancer Inst 2012;104:147-58. doi: 10.1093/jnci/djr499

53. Yang L, Francois F, Pei Z. Molecular pathways: pathogenesis and clinical implications of microbiome alteration in esophagitis and Barrett esophagus. Clin Cancer Res 2012;18:2138-44. doi: 10.1158/1078-0432.CCR-11-0934

54. Gao S, Li S, Ma Z, Liang S, Shan T, Zhang M, et al. Presence of Porphyromonas gingivalis in esophagus and its association with the clinicopathological characteristics and survival in patients with esophageal cancer. Infect Agent Cancer 2016;11:3. doi: 10.1186/s13027-016-0049-x

55. Chen X, Winckler B, Lu M, Cheng H, Yuan Z, Yang Y, et al. Oral Microbiota and Risk for Esophageal Squamous Cell Carcinoma in a High-Risk Area of China. PloS One 2015;10:e0143603. doi:10.1371/journal.pone.0143603

56. Wroblewski LE, Peek RM, Wilson KT. Helicobacter pylori and gastric cancer: factors that modulate disease risk. Clin Microbiol Rev 2010;23:713-39. doi: 10.1128/ 


\section{CMR.00011-10}

57. Islami F, Kamangar F. Helicobacter pylori and esophageal cancer risk: a meta-analysis. Cancer Prev Res 2008;1:32938. doi: 10.1158/1940-6207.CAPR-08-0109

58. Ling ZQ, Li P, Ge MH, Hu FJ, Fang XH, Dong ZM, et al. Aberrant methylation of different DNA repair genes demonstrates distinct prognostic value for esophageal cancer. Dig Dis Sci 2011;56:2992-3004. doi: 10.1007/s10620011-1774-z

59. Rastgar Jazii F. Esophageal cancer - cell and molecular biology, biomarkers,nutrition and treatment: Janeza Trdine 9, 51000 Rijeka, Croatia 2012. 254.

60. Ye Y, Wang KK, Gu J, Yang H, Lin J, Ajani JA, et al. Genetic variations in microRNA-related genes are novel susceptibility loci for esophageal cancer risk. Cancer prev Res 2008;1:460-9. doi: 10.1158/1940-6207.CAPR-080135

61. Lehrbach DM, Nita ME, Cecconello I. Molecular aspects of esophageal squamous cell carcinoma carcinogenesis. Arq Gastroenterol 2003;40:256-61. doi : 10.1590/S000428032003000400011

62. Mandard AM, Hainaut P, Hollstein M. Genetic steps in the development of squamous cell carcinoma of the esophagus. Mutat Res 2000;462:335-42. doi:10.1016/S13835742(00)00019-3

63. Ghavam Nasiri M, Varshouei TF, Homaei shandiz F, Khajeh dalouei M, Gghafarzadegan K. Evaluation of cyclin $\mathrm{d} 1$ expression in esophageal squamous cell carcinoma and its effect on response rate to neo-adjuvant chemoradiotherapy. Iran J Pathol 2010.

64. Cui L, Pan XM, Ma CF, Shang-Guan J, Yu HB, Chen GX,et al. Association between epidermal growth factor polymorphism and esophageal squamous cell carcinoma susceptibility. Dig Dis Sci 2010;55:40-5. doi: 10.1007/ s10620-008-0700-5

65. Wang J, Yu JM, Jing SW, Guo Y, Wu YJ, Li N, et al. Relationship between EGFR Over-expression and Clinicopathologic Characteristics in Squamous Cell Carcinoma of the Esophagus: A Meta-analysis. Asian Pac J Cancer Prev 2014;15:5889-93.

66. Abedi-Ardekani B , Muzaffar Mir M. Epidermal growth factor receptor (EGFR) mutations and expression in squamous cell carcinoma of the esophagus in central Asia. BMC Cancer 2012;12:7. doi: 10.1186/1471-2407-12-602

67. McCabe ML, Dlamini Z. The molecular mechanisms of oesophageal cancer. Int Immunopharmacol 2005;5:111330. doi:10.1016/j.intimp

68. Pietsch E HO, Murphy M. Polymorphisms in the p53 pathway. Oncogene 2006;25:1602-11. doi:10.1038/ sj.onc. 1209367

69. Kuwano H, Kato H, Miyazaki T, Fukuchi M, Masuda N, Nakajima M, et al. Genetic alterations in esophageal cancer. Surg Today 2005;35:7-18. doi: 10.1007/s00595-0042885-3
70. Olivier M, Eeles R, Hollstein M, Khan MA, Harris CC, Hainaut P. The IARC TP53 database: new online mutation analysis and recommendations to users. Hum Mutat 2002;19:607-14. doi:10.1002/humu.10081

71. Kihara C, Seki T, Furukawa Y, Yamana H, Kimura Y, Schaardenburgh P, et al. Mutations in Zinc-binding Domains of p53 as a Prognostic Marker of Esophageal-cancer Patients. Cancer Sc 2000;91:190-8. doi: 10.1111/ j.1349-7006.2000.tb00931.x

72. Marjani HA BF, Hossein-Nezhad A, Islami F, Pourshmas A, Semnani Sh. Prevalence of Esophageal Cancer Risk Factors among Turkmen and Non-Turkmen Ethnic Groups in a High Incidence Area in Iran. Arch Iran Med 2010;13: 111-5.

73. 73.Abedi-Ardekani B KF, Sotoudeh M. Extremely HighTp53Mutation Load in Esophageal Squamous Cell Carcinoma in Golestan Province, Iran. PloS One 2011;6:9. doi:10.1371/journal.pone.0029488

74. La DK, Swenberg JA. DNA adducts: biological markers of exposure and potential applications to risk assessment. Mutat Res. 1996;365:129-46. doi: 10.1016/S01651110(96)90017-2

75. Taghavi N BF, Abbaszadegan M R, Khademi H, Sotoudeh M, Khoshbakht Sh. P21 (Waf1/Cip1)Gene Polymorphisms and Possible Interaction with Cigarette Smoking in Esophageal Squamous Cell Carcinoma in Northeastern Iran: A Preliminary Study. Arch Iran Med 2010;13:23542.

76. Taghavi N, Biramijamal F, Sotoudeh M, Khademi H, Malekzadeh R, Moaven O, et al. p16INK4a hypermethylation and p53, p16 and MDM2 protein expression in esophageal squamous cell carcinoma. BMC Cancer 2010;10:138. doi: 10.1186/1471-2407-10-138

77. Yoshida K, Miki Y. Role of BRCA1 and BRCA2 as regulators of DNA repair, transcription, and cell cycle in response to DNA damage. Cancer Sci 2004;95:866-71. doi: 10.1111/j.1349-7006.2004.tb02195.x

78. Akbari MR, Malekzadeh R, Nasrollahzadeh D, Amanian $\mathrm{D}$, Islami F, Li S, et al. Germline BRCA2 mutations and the risk of esophageal squamous cell carcinoma. Oncogene 2008;27:1290-6. doi:10.1038/sj.onc.1210739

79. Etemadi A, Islami F, Phillips DH, Godschalk R, Golozar A, Kamangar F, et al. Variation in PAH-related DNA adduct levels among non-smokers: the role of multiple genetic polymorphisms and nucleotide excision repair phenotype. Int J Cancer 2013;132:2738-47. doi: 10.1002/ ijc. 27953

80. Morita M, Kumashiro R, Kubo N, Nakashima Y, Yoshida $\mathrm{R}$, Yoshinaga $\mathrm{K}$, et al. Alcohol drinking, cigarette smoking, and the development of squamous cell carcinoma of the esophagus: epidemiology, clinical findings, and prevention. Int J Clin Oncol 2010;15:126-34. doi: 10.1007/ s10147-010-0056-7

81. Roth MJ, Wei WQ, Baer J, Abnet CC, Wang GQ, Sternberg LR, et al. Aryl hydrocarbon receptor expression is associated with a family history of upper gastrointestinal 
tract cancer in a high-risk population exposed to aromatic hydrocarbons. Cancer Epidemiol Biomarkers Prev 2009;18:2391-6. doi: 10.1158/1055-9965.EPI-08-1098

82. Sepehr A, Kamangar F, Abnet CC, Fahimi S, Pourshams A, Poustchi H, et al. Genetic polymorphisms in three Iranian populations with different risks of esophageal cancer, an ecologic comparison. Cancer Lett 2004;213:195-202. doi:10.1016/j.canlet.2004.05.017

83. Mosavi -Jarrahi A MM. Epidemiology of Esophageal Cancer in the High-Risk Population. Asian Pacific J Cancer Prev 2006;7:375-80.

84. Akbari MR, Malekzadeh R, Shakeri R, Nasrollahzadeh D, Foumani M, Sun Y, et al. Candidate gene association study of esophageal squamous cell carcinoma in a highrisk region in Iran. Cancer Res 2009;69:7994-8000. doi: 10.1158/0008-5472.CAN-09-1149

85. Islami F, Boffetta P, van Schooten FJ, Strickland P, Phillips DH, Pourshams A, et al. Exposure to Polycyclic Aromatic Hydrocarbons Among Never Smokers in Golestan Province, Iran, an Area of High Incidence of Esophageal Cancer - a Cross-Sectional Study with Repeated Measurement of Urinary 1-OHPG in Two Seasons. Front Oncol 2012;2:14. doi: 10.3389/fonc. 2012.00014

86. Shimada T. Xenobiotic-metabolizing enzymes involved in activation and detoxification of carcinogenic polycyclic aromatic hydrocarbons. Drug Metab Pharmacokinet 2006;21:257-76. doi :10.2133/dmpk.21.257

87. Yanling H, Yuhong Z, Wenwu H, Lei X, Mingwu C. NQO1 C609T polymorphism and esophageal cancer risk: a HuGE review and meta-analysis. BMC Med Genet 2013;14:31. doi: 10.1186/1471-2350-14-31

88. Marjani H, Rakhshani N. Investigation of NQO1 genetic polymorphism, NQO1 gene expression and PAH-DNA adducts in ESCC. A case-control study from Iran. Genet Mol Res 2010;9:239-49. doi: 10.4238/vol9-1gmr693

89. van Gijssel HE. Semiquantitation of polycyclic aromatic hydrocarbon-DNA adducts in human esophagus by immunohistochemistry and the automated cellular imaging system. Cancer Epidemiol Biomarkers Prev 2002;11:1622-9.

90. Akbari MR, Malekzadeh R, Lepage P, Roquis D, Sadjadi AR, Aghcheli K, et al. Mutations in Fanconi anemia genes and the risk of esophageal cancer. Hum Genet 2011;129:573-82. doi: 10.1007/s00439-011-0951-7

91. Shen YG, Xu YJ, Shi ZL, Han HL, Sun DQ, Zhang X. Effects of RNAi-mediated matrix metalloproteinase-2 gene silencing on the invasiveness and adhesion of esophageal carcinoma cells, KYSE150. Dig Dis Sci 2012;57:32-7. doi: 10.1007/s10620-011-1864-y

92. Koyama H, Iwata H, Kuwabara Y, Iwase H, Kobayashi S, Fujii Y. Gelatinolytic activity of matrix metalloproteinase-2 and -9 in oesophageal carcinoma; a study using in situ zymography. Eur J Cancer 2000;36:2164-70.

93. Kaderlik KR, Talaska G, DeBord DG, Osorio AM, Kadlubar FF.. 4,4[prime]-Methylene-bis(2-chloroaniline)DNA adduct analysis in human exfoliated urothelial cells by 32P-postlabeling. Cancer Epidemiol Biomarkers Prev 1993;2:63-9.

94. Yamamoto K OM, Hayashi H, Tangoku A, Gondo T, Suzuki T. CYFRA 21-1 is a useful marker for esophageal squamous cell carcinoma. Cancer 1997;79:1647-55. doi: 10.1002/(SICI)1097-0142(19970501)79:9<1647:AIDCNCR3 $>3.0 . \mathrm{CO} ; 2-9$

95. Zhang J, Wang K, Zhang J, Liu SS, Dai L, Zhang JY. Using proteomic approach to identify tumor-associated proteins as biomarkers in human esophageal squamous cell carcinoma. J Proteome Res 2011;10:2863-72. doi: $10.1021 / \mathrm{pr} 200141 \mathrm{c}$

96. Genasetti A, Vigetti D, Viola M, Karousou E, Moretto P, Rizzi M, et al. Hyaluronan and human endothelial cell behavior. Connec Tissue Res 2008;49:120-3. doi: 10.1080/03008200802148462

97. Rosa H, Parise ER. Is there a place for serum laminin determination in patients with liver disease and cancer? World J Gastroenterol 2008;14:3628-32. doi:10.3748/ wjg. 14.3628

98. Aghcheli K, Parsian H, Qujeq D, Talebi M, Mosapour A, Khalilipour E, et al. Serum hyaluronic acid and laminin as potential tumor markers for upper gastrointestinal cancers. Eur J Inter Med 2012;23:58-64. doi: 10.1016/j. ejim.2011.07.018

99. Jazii FR, Najafi Z, Malekzadeh R, Conrads TP, Ziaee AA, Abnet $\mathrm{C}$,et al. Identification of squamous cell carcinoma associated proteins by proteomics and loss of beta tropomyosin expression in esophageal cancer. World J Gastroenterol 2006;12:7104-12. doi: 10.3748/wjg.v12.i44.7104

100. Hu Y, Correa AM, Hoque A, Guan B, Ye F, Huang J, et al. Prognostic significance of differentially expressed miRNAs in esophageal cancer. Inter J Cancer 2011;128:13243. doi: $10.1002 /$ ijc. 25330

101. Matsushima K, Isomoto H, Kohno S, Nakao K. MicroRNAs and esophageal squamous cell carcinoma. Digestion 2010;82:138-44. doi:10.1159/000310918

102. Alder H, Taccioli C, Chen H, Jiang Y, Smalley KJ, Fadda $\mathrm{P}$, et al. Dysregulation of miR-31 and miR-21 induced by zinc deficiency promotes esophageal cancer. Carcinogenesis 2012;33:1736-44. doi: 10.1093/carcin/bgs204

103. Guo Y, Chen Z, Zhang L, Zhou F, Shi S, Feng X, et al. Distinctive microRNA profiles relating to patient survival in esophageal squamous cell carcinoma. Cancer Res 2008;68:26-33. doi: 10.1158/0008-5472

104. Mathe EA, Nguyen GH, Bowman ED, Zhao Y, Budhu A, Schetter AJ, et al. MicroRNA expression in squamous cell carcinoma and adenocarcinoma of the esophagus: associations with survival. Clin Cancer Res 2009;15:6192-200. doi: 10.1158/1078-0432.CCR-09-1467

105. Zhang H, Li M, Han Y, Hong L, Gong T, Sun L, et al. Down-regulation of miR-27a might reverse multidrug resistance of esophageal squamous cell carcinoma. Dig Dis Sci 2010;55:2545-51. doi: 10.1007/s10620-009-1051-6

106. Li P, Mao WM, Zheng ZG, Dong ZM, Ling ZQ. Down- 
regulation of PTEN expression modulated by dysregulated miR-21 contributes to the progression of esophageal cancer. Dig Dis Sci 2013;58:3483-93. doi: 10.1007/ s10620-013-2854-z

107. Shakeri R, Kamangar F, Nasrollahzadeh D, Nouraie M, Khademi H, Etemadi A, et al. Is opium a real risk factor for esophageal cancer or just a methodological artifact? Hospital and neighborhood controls in case-control studies. PloS One 2012;7:e32711. doi:10.1371/journal. pone. 0032711

108. Dey B, Raphael V, Khonglah Y, GiriLynrah K. Expression of Cyclin D1 and P16 in Esophageal Squamous Cell Carcinoma. Middle East J Dig Dis 2015;7:220-5.

109. Biramijamal F, Allameh A, Mirbod P, Groene H-J, Koomagi R, Hollstein M. Unusual profile and high prevalence of $\mathrm{p} 53$ mutations in esophageal squamous cell carcinomas from northern Iran. Cancer Res 2001;61:3119-23.

110. Taghavi N. Association of p53/p21 expression with cigarette smoking and prognosis in esophageal squamous cell carcinoma patients. World J Gastroenterol 2010;16:4958. doi: 10.3748/wjg.v16.i39.4958

111. Ishida M, Morita M, Saeki H, Ohga T, Sadanaga N, Watanabe M, et al. Expression of p53 and p21 and the clinical response for hyperthermochemoradiotherapy in patients with squamous cell carcinoma of the esophagus. Anticancer Res 2007;27:3501-6.

112. Chen W, Yang C, Yang L, Qi C, Tian S, Han Y, et al. Association of roasting meat intake with the risk of esophageal squamous cell carcinoma of Kazakh Chinese via affecting promoter methylation of'p16'gene. Asia Pac J Clin Nutr 2014;23:488. doi: 10.6133/apjen.2014.23.3.11

113. Bai P, Xiao X, Zou J, Cui L, Bui Nguyen TM, Liu J, et al. Expression of p14ARF, p15INK4b, p16INK4a and skp2 increases during esophageal squamous cell cancer progression. Exp Ther Med 2012;3:1026-32. doi:10.3892/ etm.2012.523 